\title{
ÚJRAERDŐSÍTÉS HATÁSA A TALAJ TULAJDONSÁGAIRA ÉS A MEZOFAUNÁRA (COLLEMBOLA) EGYKORI SZÁNTÓFÖLDI MŰTRÁGYÁZÁSI TARTAMKÍSÉRLETI TERÜLETEN
}

\author{
Harta István ${ }^{1}$, Winkler Dániel² és Füleky György ${ }^{1}$ \\ ${ }^{1}$ Szent István Egyetem, Környezettudományi Intézet \\ ${ }^{2}$ Soproni Egyetem, Vadgazdálkodási és Gerinces Állattani Intézet
}

\begin{abstract}
Kivonat
A gödöllői Szent István Egyetem két korábbi mütrágyázási tartamkísérleti területén ma fehér akác (Robinia pseudoacacia) és kocsánytalan tölgy (Quercus petraea) faültetvény található. Kutatásunk során a kísérleti területek korábban legnagyobb adagú mütrágyával kezelt parcelláinak talajparamétereit és ugróvillás (Collembola) faunáját vizsgáltuk. Kontroll élőhelyként akácos és kocsánytalan tölgyes állományok, mezeijuharos-tölgyes reliktumfolt, valamint művelt és felhagyott szántó szolgáltak. A talajtulajdonságok és a talajfauna eredmények alapján az újraerdősített területek a kontroll erdőkhöz hasonlóak leginkább, ugróvillás faunájuk átmeneti jellegü, a nyillt és erdei közösségek fajai egyaránt megtalálhatóak benne. A kísérleti területek abundancia, fajszám és diverzitásértékei elmaradnak a kontroll erdőállományokétól, a szántóterületek faunájával összehasonlítva azonban szignifikánsan magasabb diverzitás figyelhető meg. Az akác ültetvényben magasabb volt az ugróvillás-sürüség, de a fajgazdagság, diverzitás és egyenletesség a kocsánytalan tölgy ültetvényben volt a magasabb. A Bray-Curtis hasonlósági mutató alapján a nyílt és erdei közösségek jól elkülönülnek, az erdőtelepítések és a kontroll erdők külön alcsoportot alkotnak.
\end{abstract}

Kulcsszavak: talajfauna, Robinia pseudoacacia, Quercus petraea, újraerdősítés, talajkémia

\section{EFFECT OF REFORESTATION ON SOIL PROPERTIES AND MESOFAUNA (COLLEMBOLA) IN A FORMER LONG-TERM FERTILIZATION EXPERIMENTAL AREA}

\begin{abstract}
Reforestation with black locust (Robinia pseudoacacia) and sessile oak (Quercus petraea) has occurred on two former fertilization experimental areas of Szent István University in Gödöllö. The aim of this study was to investigate the soil parameters and the Collembola fauna in the previously highest fertilizer-treated parcels. Nerby control sites (black locust forest, sessile oak forest, relict forest, as well as cultivated and abandoned arable land) have been selected for comparative analyses. Based on the results, the reforested areas were most similar to the control forests. Their Collembola fauna are transitional, species typical for both open areas and forests have also been detected. While the abundance, species richness and diversity of the experimental areas are still lower than in the control forests, we observed significantly higher
\end{abstract}


diversity when compared to the communities found in the cultivated arable fields. While Collembola were slightly more abundant in the black locust plantation, species richness, diversity and evenness values were higher in the sessile oak plantation. Based on the Bray-Curtis similarity measure, open and forest communities clearly separated, moreover, the studied plantations and control forests formed separate subgroups.

Keywords: soil biota, Robinia pseudoacacia, Quercus petraea, reforestation, soil chemistry

\section{BEVEZETÉS}

Az erdőterületek növelése, így a gyenge minőségủ szántók visszaerdősitése szerepel az Európai Unió agrárpolitikájának célkitűzései között (CEU 2014), de világviszonylatban is fontos megállapodások születtek a témában (UN 2014, UNEP 2014). Globális szinten az erdők nagymértékü csökkenése tapasztalható, aminek komoly hatásai vannak a társadalmakra és a gazdaságra is (Meyfroidt \& Lambin 2011). Az erdők jelentős része a változó klíma és a szárazodó éghajlat hatásainak erősebben kitett (Dale et al 2001). Az újraerdősitést követően létrejött faállományok nem rendelkeznek olyan komplex struktúrával, mint a természetes erdők (Cunningham et al 2015), azonban ellensúlyozzák a klímaváltozás hatásait (Hooper et al 2005), mérséklik a napsugárzást és a szélsebességet (Cunningham et al 2015), csökkentik a talajeróziót, növelik az élőhelyek számát és a biodiverzitást (Jackson et al. 2005), kapcsolatot teremtenek a populációk között, segítik a génáramlást (Gilbert-Norton et al. 2010), de fontos szerepük van a szén, az oxigén és a tápanyagok biogeokémiai körforgalmában is (Arneth et al. 2010). Az erdök jóval több légköri eredetủ szenet raktároznak biomasszájukban, mint a szántók vagy a legelők (Pan et al. 2011).

Kutatásunk során két, korábban szántóföldi mütrágyázási tartamkísérletként használt, újraerdősített területet vizsgáltunk, kontrollterületekkel összehasonlítva. A gödöllöi Szent István Egyetem szárítópusztai kísérleti telepén található két kísérleti területen jelenleg fehér akác (Robinia pseudoacacia) és kocsánytalan tölgy (Quercus petraea) állományok találhatók. A területen a klimatikus és edafikus adottságoknak megfelelő eredeti vegetáció az erdő. Az állománytelepités óta kevés kutatás zajlott itt (Ockert 2006, Szováti et al 2006, Tolner et al 2010, Harta et al 2016), de világszinten is kevés publikáció foglalkozik a mütrágyázás erdőkre gyakorolt hatásával (Burner 2005, Gruenewald et al 2007, Mäkipää 1994, Mirmanto et al 1999, Plass 1972, Tanner et al 1992, Turkington et al 1998). A mütrágyázás azonban hatással van a talajok kémiai és fizikai tulajdonságaira, valamint a talaj-növény tápanyagforgalomra (Haynes \& Naidu 1998, Kádár et al 2007, Kovács \& Füleky 1991), így hosszútávú hatásainak vizsgálata szükségszerü (Németh \& Várallyay 1998).

A talaj megfelelő tápanyagforgalmának elengedhetetlen feltétele a mezofauna jelenléte (Giller et al 1997), melynek egyik legfontosabb csoportját az ugróvillások (Collembola) jelentik. Jelentőségük abban áll, hogy elősegítik a szerves anyagok mineralizációját és a mikorrhiza gombák terjesztését (Hopkin 1997, Lavelle et al 1997, Coleman 2008). A bioindikáció-analízishez cönológiai jellemzőik miatt kiváló indikátorok, a legalkalmasabb tesztcsoportok közé tartoznak (Hopkin 1997, Van Straalen 1997). A szenynyezésekre, a környezeti változásokra, vagy a gazdálkodási mód megváltozására is egyértelműen reagálnak (Paul et al 2011, Sousa et al 2006). A mütrágyázás és a talaj biológiai tulajdonságai közötti összefüggések nem egészen tisztázottak (Giller et al 1997), így célunk, hogy a hosszú idejü mütrágyázást követő újraerdősítés hatását értékeljük a talaj mezofaunájának kiválasztott indikátor szervezeteivel (Collembola). 


\section{ANYAG ÉS MÓDSZER}

\section{Vizsgálati terület}

Vizsgálatainkat a Szent István Egyetem szárítópusztai kísérleti telepén lévő két mütrágyázási tartamkísérletben, illetve 5 kontrollterületen végeztük (Gödöllö, Pest megye). A kontrollterületeket úgy jelöltük ki, hogy a művelt és a művelésből kivont szántók, a környékbeli erdők, illetve a táj őshonos zárótársulása is reprezentálva legyenek. A tölgyes kísérleti terület (T5) és az akácos kísérleti terület (A12) mellett a kontrollterületek így egy művelt szántó (SZ), felhagyott szántó (FSZ), akác kontroll (AK), tölgyes kontroll (TK) és a SZIE Botanikus Kertjében található gyertyánelegyes mezeijuharos-tölgyes reliktumfolt (RT) (Aceri campestri-Quercetum petraeae-roboris) lettek (1 ábra).

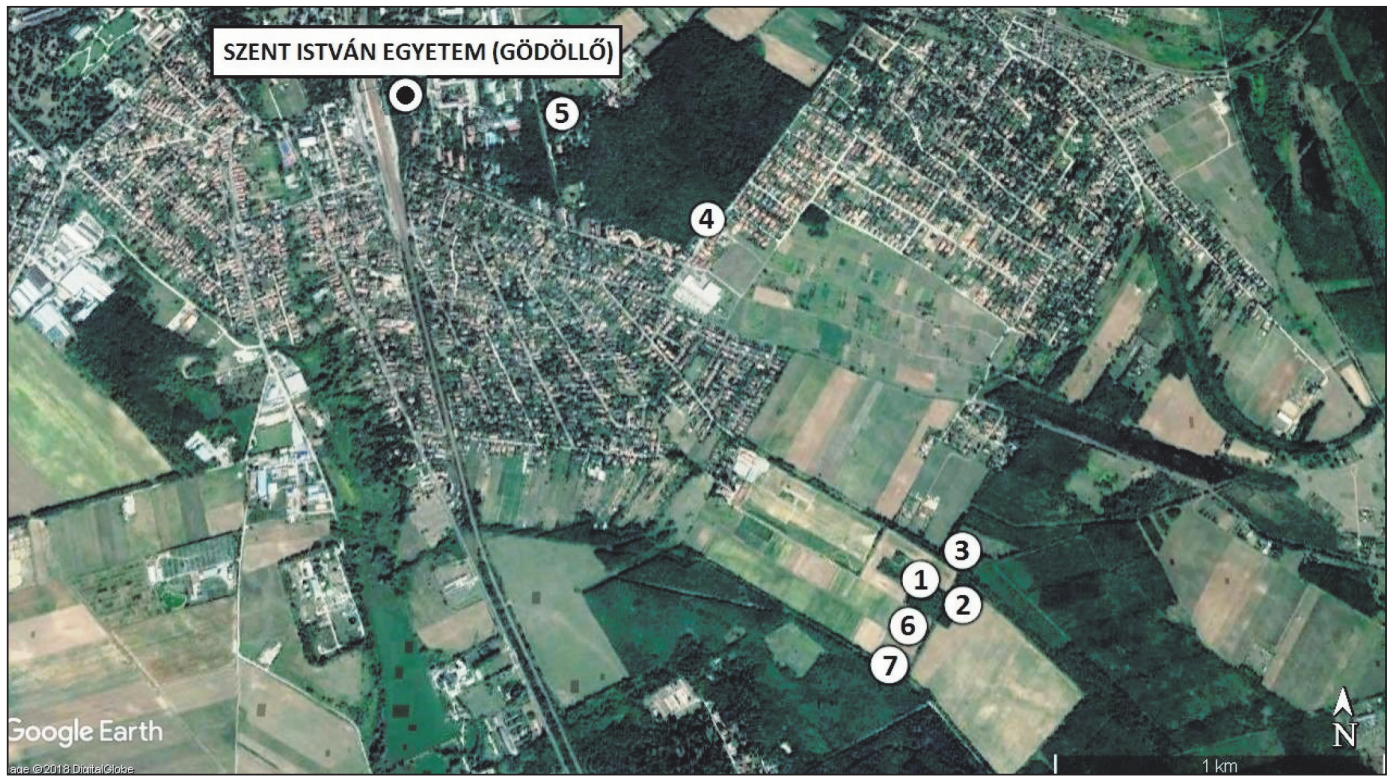

1. ábra: $A$ kutatási területek elhelyezkedése - mintavételi helyek

1 - akácos kísérleti terület (A12), 2 - kocsánytalan tölgyes kísérleti terület (T5), 3 - akác kontroll (AK),

4 - kocsánytalan tölgyes kontroll (TK), 5 - reliktum tölgyes (RT), 6 - szántó (SZ), 7 - felhagyott szántó (FSZ)

Figure 1: Location of the study area - sampling sites

1 - Black locust experimental stand (A12), 2 - Sessile oak experimental stand (T5), 3 - Black locust control (AK), 4 - Sessile oak control (TK), 5-Relict forest (RT), 6-Arable land (SZ), 7 - Uncultivated arable land (FSZ)

A mintaterületek a Gödöllöi-dombság kistájban találhatók, 230-240 m terngerszint feletti magasságban. A klíma mérsékelten száraz kontinentális, az átlagos évi csapadékmennyiség 540-580 mm, az átlagos évi középhömérséklet $9,5-10,0^{\circ} \mathrm{C}$ (Dövényi 2010). A kísérleti területeken $60-90 \mathrm{~cm}$ vastag Ramann-féle barna erdőtalaj (rozsdabarna erdőtalaj - Luvic Calcic Phaeozem altípus) található, lösszel kevert homok alapkőzeten (Stefanovits 1972). A 0-20 cm textúrája vályogos homok, sürüsége átlagosan $1,58 \mathrm{~g}^{\circ} \mathrm{cm}^{-3}$, a teljes porozitás $51,2 \%$, a gravitációs pórusok aránya $20,7 \%$ (Ockert 2006). A talaj tápanyagellátottsága és vízháztartása alapvetően gyenge (Kovács \& Füleky 1991).

A két kísérleti terület $(A ; T)$ teljes nettó területe $11900 \mathrm{~m}^{2}$. Mindkét erdőállományban a korábban legnagyobb műtrágyadózissal kezelt parcellákat választottunk ki, kétszer $420 \mathrm{~m}^{2}$ területen. A tölgyerdő kísérlet korábban vetésforgó műtrágyázási tartamkísérlet volt, 1972-ben létesítették. Itt NPK-mütrágyázás folyt 
5 különböző mütrágyaszinten, növekvő adagokban. Az „A” szakaszra, 1998-ban kocsánytalan tölgy (Quercus petraea) telepítése történt, a kísérlet többi részét megszűntették. Jelen kutatásban a legnagyobb (T5) korábbi kezelést vizsgáltuk. Az akácerdő kísérlet korábban kukorica monokultúra mütrágyázási tartamkísérletet volt, 1970-ben létesitették. Akkor 20 éven keresztül az eltérő mennyiségü és arányú NPK-műtrágyázás hatásait vizsgálták, majd 1995 őszén Pusztavacsról származó fehér akác (Robinia pseudoacacia) telepítése történt. A területen 12 különböző mütrágyázási dózist alkalmaztak, melyből jelen kutatásban a legnagyobb (A12) korábbi kezelést vizsgáltuk. A két kísérleti terület kiválasztott legnagyobb kezelésire összesen kijuttatott hatóanyagmennyiségeket az 1. táblázat tartalmazza.

1. táblázat: A kocsánytalan tölgyes kísérleti terület (T5) és az akácos kísérleti terület (A12) kiválasztott mintaterületein alkalmazott mütrágyakezelések, az ültetvények telepitése elött

Table 1: Fertilizer doses applied in the study area before the plantation of the sessile oak (T5) and black locust (A12) stands

\begin{tabular}{|c|c|c|c|c|}
\hline \multirow{2}{*}{} & \multicolumn{4}{|c|}{ Kijuttatott mütrágya-hatóanyag } \\
\cline { 2 - 5 } & $\mathbf{N}$ & $\mathrm{P}_{2} \mathrm{O}_{5}$ & $\mathrm{~K}_{2} \mathrm{O}$ & Össz. \\
\hline \multirow{2}{*}{ T5 } & \multicolumn{4}{|c|}{$\mathrm{kg}^{*} \mathrm{ha}^{-1}{ }^{*} 25 \mathrm{év}^{-1}$} \\
\cline { 2 - 5 } & 7530 & 4510 & 5428 & 17468 \\
\hline \multirow{2}{*}{ A12 } & \multicolumn{4}{|c|}{$\mathrm{kg}^{*} \mathrm{ha}^{-1}{ }^{*} 20 \mathrm{év}^{-1}$} \\
\cline { 2 - 5 } & 7200 & 4800 & 4000 & 16000 \\
\hline
\end{tabular}

\section{Gyüjtési és kiértékelési módszerek}

A talaj $(0-20 \mathrm{~cm})$ vizsgálatához minden mintaterületröl 5 talajmintát $(\mathrm{kb} .50 \mathrm{~g})$ gyüjtöttünk, véletlenszerűen, 3 ismétlésben. Az ugyanarról a mintaterületről származó 5 talajmintát összekevertük, így összesen $21 \mathrm{db}$ kompozit mintát kaptunk. A légszárazra szárítás után a talajmintákat összetörtük, majd 2,0 mm átmérőjü szitán átszitáltuk. Minden mintából meghatároztuk a desztillált vizes $\left(\mathrm{pH}_{\mathrm{H} 2 \mathrm{O}}\right)$ és a kálium-kloridos $\left(\mathrm{pH}_{\mathrm{KCl}}\right) \mathrm{pH}$-t (Buzás 1988), Tyurin módszerrel, $\mathrm{K}_{2} \mathrm{Cr}_{2} \mathrm{O}_{7}$ és $\mathrm{H}_{2} \mathrm{SO}_{4}$ segítségével a humusztartalmat ( $\mathrm{H} \%$ ) (Buzás 1988), a KCl-oldható $\mathrm{NO}_{3}{ }^{-}$és $\mathrm{NH}_{4}{ }^{+}$tartalmat (Bacsó et al. 1972), az ammónium-laktát-oldható P- és K-tartalmat $\left(\mathrm{AL}-\mathrm{P}_{2} \mathrm{O}_{5}, \mathrm{AL}-\mathrm{K}_{2} \mathrm{O}\right)$ (Egnér et al. 1960), a mésztartalmat $\left(\mathrm{CaCO}_{3}\right)$ (Buzás 1988) és az Arany-féle kötöttséget $\left(K_{A}\right)$ (Buzás 1993).

A talajparaméterek közötti statisztikai különbség kimutatásához egytényezős variancia-analízist használtunk, ahol az SzD-értéket 5\%-os hibahatárral adtuk meg.

Az ugróvillások kimutatásához minden kiválasztott mintaterületröl 5 talajmintát gyüjtöttünk hossztengelyében két palástra osztott fémhengerrel $\left(100 \mathrm{~cm}^{3}, d=3,6 \mathrm{~cm}, \mathrm{~h}=10,0 \mathrm{~cm}\right)$, véletlenszerüen. A mintákból az ugróvillásokat 14 napos futtatással nyertük ki, Berlese-Tullgren futtatók segítségével. Az egyes fajokat a főbb taxonómiai kulcsok (Deharveng 1982, Fjellberg 1980, 1998, Babenko et al 1994, Zimdars \& Dunger 1994, Weiner 1996, Jordana et al. 1997, Pomorski 1998, Bretfeld 1999, Potapov 2001, Thibaud et al. 2004, Jordana 2012) segítségével határoztuk meg. Az ugróvillások rendszertani áttekintésénél a magyar fauna besorolását (Dányi \& Traser 2008) vettük alapul.

A közösségi-ökológiai elemzés során a fajszám, abundancia- és dominancia-viszonyok, fontosabb közösségi karakterisztikák - Shannon diverzitás (Shannon \& Weaver 1949), kiegyenlítettség (Pielou 1966) - segítségével végeztük el az egyes habitatok összehasonlító értékelését. A diverzitások statisztikai összehasonlítását a Hutcheson-féle módosított t-próbával végeztük el (Hutcheson 1970). 
A vizsgált élőhelyek hasonlóságát az ugróvillás-közösségek Bray-Curtis-féle hasonlóságmérésén alapuló klaszteranalízis segítségével vizsgáltuk (Bray \& Curtis 1957).

Az elemzéseket az SPSS vs20 (IBM Corp. 2011) és a Past ver 2.17b (Hammer et al 2001) segítségével végeztük el.

\section{EREDMÉNYEK}

\section{Talajeredmények}

A mért talajparamétereket a 2. táblázat tartalmazza, a számolt $\mathrm{SzD}_{5 \%}$ értékekkel. $\mathrm{A} \mathrm{CaCO}_{3}$-tartalom a legtöbb minta esetében $0 \%$ volt, így nem lehetett varianciaanalízist végezni az adatokkal. A felhagyott szántó (FSZ) esetében a karbonáttartalom átlaga $0,85 \%$, míg a kontroll akácos (AK) esetében 1,82\% volt.

A tölgyes kísérlet (T5) a talaj 0-20 cm-es rétegének paraméterei alapján a kontroll tölgyestöl (TK) foszfortartalom, káliumtartalom és $\mathrm{K}_{\mathrm{A}}$, a szántótól (SZ) $\mathrm{pH}_{\mathrm{H} 2 \mathrm{O}}$, humusztartalom, foszfortartalom és $\mathrm{K}_{\mathrm{A}}$, a felhagyott szántóterülettöl (FSZ) mindkét pH, foszfortartalom és $\mathrm{K}_{\mathrm{A}}$, a reliktum tölgyestöl (RT) a káliumtartalom kivételével minden paraméter esetében szignifikánsan különbözik.

Az akácos kísérlet (A12) a talaj 0-20 cm-es rétegének paraméterei alapján a tölgyes kísérlettől (T5) mindkét pH, illetve foszfor- és a káliumtartalom, a szántótól (SZ) humusztartalom, $\mathrm{pH}_{\mathrm{KCl}}$, és $\mathrm{K}_{\mathrm{A}}$, a felhagyott szántótól (FSZ) foszfortartalom és $K_{A}$, a reliktum tölgyestől (RT) a foszfortartalom kivételével minden paraméter esetében szignifikánsan különbözik. A kontroll akácostól (AK) egyik paraméter tekintetében sincs statisztikailag igazolható különbség.

2. táblázat: $A$ kísérleti ültetvények és a kontrollterületek talajának $(0-20 \mathrm{~cm})$ paraméterei A12 - akácos kísérleti terület, AK - akác kontroll, T5 - kocsánytalan tölgyes kísérleti terület, TK - kocsánytalan tölgy kontroll, RT - reliktum tölgyes, SZ - szántó, FSZ - felhagyott szántó

Table 2: Soil parameters in the studied plantations and control sites

A12 - Black locust experimental stand, AK - Black locust control, T5 - Sessile oak experimental stand,

TK - Sessile oak control, RT - Relict forest, SZ - Arable land, FSZ - Uncultivated arable land

\begin{tabular}{|c|c|c|c|c|c|c|c|}
\hline & & & Humusz & AL- $\mathrm{P}_{2} \mathrm{O}_{5}$ & $\mathrm{AL}-\mathrm{K}_{2} \mathrm{O}$ & $\mathrm{NO}_{3}{ }^{-}+\mathrm{NH}_{4}^{+}$ & \\
\hline & $\mathrm{PH}_{\mathrm{KCl}}$ & $\mathrm{PH}_{\mathrm{H} 2 \mathrm{O}}$ & $\%$ & & $\mathrm{mg} / \mathrm{kg}$ & & $\mathrm{n}_{\mathrm{A}}$ \\
\hline $\mathrm{A} 12$ & 6,26 & 6,85 & 2,22 & 45,60 & 188,33 & 9,00 & 28,33 \\
\hline AK & 6,05 & 6,68 & 1,46 & 87,83 & 145,67 & 9,03 & 27,33 \\
\hline T5 & 4,56 & 5,57 & 2,11 & 280,00 & 270,33 & 12,83 & 27,00 \\
\hline TK & 4,95 & 5,86 & 2,01 & 27,25 & 126,37 & 10,93 & 32,00 \\
\hline RT & 3,63 & 4,56 & 3,97 & 68,80 & 298,67 & 35,07 & 43,67 \\
\hline SZ & 5,21 & 6,27 & 0,83 & 100,30 & 243,67 & 6,33 & 21,33 \\
\hline FSZ & 6,48 & 7,07 & 2,19 & 172,53 & 217,67 & 8,23 & 32,67 \\
\hline $\mathrm{SzD}_{5 \%}$ & 0,82 & 0,64 & 1,09 & 71,87 & 71,56 & 15,20 & 3,27 \\
\hline
\end{tabular}

\section{Faunisztikai eredmények}

A vizsgálat során gyüjtött mintákból összesen 76 ugróvillás faj került elő. A fajok abundanciaértékeit a vizsgált habitatokban a 3. táblázat foglalja össze. Az egyes ugróvillás csoportok megoszlása alapján megállapítható, hogy a legnagyobb fajszámmal az Entomobryidae család képviselt, ugyanakkor szembetünő az Isotomidae család kiemelkedő abundanciája. Ez elsősorban néhány, időszakos tömegszaporodásra is hajla- 
mos faj (pl. Folsomia manolachei, F. quadrioculata, Parisotoma notabilis) kiugróan magas egyedszámának köszönhető. A vizsgálati terület geográfiai és klimatikus viszonyainak megfelelően számos xerotermofil ugróvillás (pl. Mesaphorura critica, Metaphorura denisi, Entomobrya multifasciata, Orchesella cincta) került elő a gyüjtött mintákból. Az akáccal és kocsánytalan tölggyel újraerdősített mintaterületeken az állományok fiatal kora és környező habitatok (szántó, felhagyott szántó, erdősáv) miatt kevés a tipikusan erdőlakó fajok (Ceratophysella luteospina, Neanura muscorum, Entomobrya muscorum) száma, ugyanakkor több, elsősorban a nyíltabb élőhelyekre jellemző faj (pl. Pseudachorutes pratensis, Lepidocyrtus cyaneus) is megtalálható még.

3. táblázat: Az elôforduló Collembola fajok átlagos abundanciája (egyed $/ \mathrm{m}^{2}$ ) a vizsgált élőhelyeken A12 - akácos kísérleti terület, AK - akác kontroll, T5 - kocsánytalan tölgyes kísérleti terület,

TK - kocsánytalan tölgy kontroll, RT - reliktum tölgyes, SZ - szántó, FSZ - felhagyott szántó

Table 3: Collembola species spectrum and mean abundance (ind. $/ \mathrm{m}^{2}$ ) in the sampled habitats A12 - Black locust experimental stand, AK - Black locust control, T5 - Sessile oak experimental stand,

TK - Sessile oak control, RT - Relict forest, SZ - Arable land, FSZ - Uncultivated arable land

\begin{tabular}{|c|c|c|c|c|c|c|c|}
\hline Collembola & A12 & AK & T5 & TK & RT & Sz & FSZ \\
\hline \multicolumn{8}{|l|}{ Brachystomellidae } \\
\hline Brachystomella parvula (Schäffer, 1896) & 0 & 0 & 0 & 0 & 0 & 213 & 27 \\
\hline \multicolumn{8}{|l|}{ Hypogastruridae } \\
\hline Ceratophysella luteospina (Stach, 1920) & 0 & 127 & 20 & 0 & 0 & 0 & 0 \\
\hline Ceratophysella succinea (Gisin, 1949) & 0 & 0 & 0 & 0 & 0 & 913 & 327 \\
\hline Choreutinula inermis (Tullberg, 1871) & 0 & 0 & 0 & 0 & 140 & 0 & 0 \\
\hline Hypogastrura socialis (Uzel, 1891) & 0 & 0 & 0 & 0 & 0 & 0 & 1427 \\
\hline Hypogastrura vernalis (Carl, 1901) & 0 & 0 & 0 & 0 & 0 & 0 & 467 \\
\hline Willemia virae Kaprus, 1997 & 193 & 147 & 280 & 393 & 20 & 133 & 487 \\
\hline Xenylla brevisimilis Stach, 1949 & 0 & 33 & 0 & 0 & 0 & 0 & 0 \\
\hline \multicolumn{8}{|l|}{ Neanuridae } \\
\hline Deutonura conjuncta (Stach, 1926) & 0 & 0 & 0 & 7 & 40 & 0 & 0 \\
\hline Friesea truncata Cassagnau, 1958 & 0 & 0 & 0 & 0 & 0 & 0 & 7 \\
\hline Neanura muscorum (Templeton, 1835) & 0 & 0 & 27 & 67 & 247 & 0 & 0 \\
\hline Pratanurida cassagnaui Rusek, 1973 & 0 & 0 & 0 & 0 & 0 & 0 & 7 \\
\hline Pseudachorutes dubius Krausbauer, 1898 & 0 & 0 & 0 & 40 & 7 & 0 & 0 \\
\hline Pseudachorutes parvulus Börner, 1901 & 7 & 0 & 33 & 0 & 313 & 0 & 0 \\
\hline Pseudachorutes pratensis Rusek, 1973 & 0 & 0 & 0 & 0 & 0 & 0 & 13 \\
\hline Pseudachorutes subcrassus Tullberg, 1871 & 0 & 0 & 0 & 67 & 0 & 0 & 0 \\
\hline \multicolumn{8}{|l|}{ Odontellidae } \\
\hline Superodontella lamellifera (Axelson, 1903) & 0 & 0 & 0 & 0 & 40 & 0 & 0 \\
\hline \multicolumn{8}{|l|}{ Onychiuridae } \\
\hline Protaphorura armata (Tullberg, 1869) & 347 & 487 & 747 & 620 & 700 & 13 & 933 \\
\hline Protaphorura cancellata (Gisin, 1956) & 0 & 0 & 0 & 0 & 0 & 0 & 20 \\
\hline Protaphorura campata (Gisin, 1952) & 47 & 0 & 20 & 27 & 380 & 0 & 0 \\
\hline Protaphorura subarmata (Gisin, 1957) & 0 & 0 & 0 & 0 & 0 & 0 & 13 \\
\hline
\end{tabular}


A 3. táblázat (folytatás)

Table 3. (cont.)

\begin{tabular}{|c|c|c|c|c|c|c|c|}
\hline Collembola & A12 & AK & T5 & TK & RT & SZ & FSZ \\
\hline \multicolumn{8}{|l|}{ Tullbergiidae } \\
\hline Mesaphorura critica Ellis, 1976 & 373 & 360 & 93 & 27 & 0 & 140 & 373 \\
\hline Mesaphorura italica (Rusek, 1971) & 53 & 40 & 0 & 0 & 0 & 27 & 220 \\
\hline Mesaphorura krausbaueri Börner, 1901 & 453 & 420 & 100 & 320 & 100 & 0 & 0 \\
\hline Mesaphorura macrochaeta Rusek, 1976 & 180 & 273 & 27 & 167 & 0 & 113 & 447 \\
\hline Mesaphorura yosii (Rusek, 1967) & 0 & 0 & 0 & 0 & 0 & 27 & 0 \\
\hline Metaphorura denisi Simon, 1985 & 0 & 0 & 0 & 0 & 0 & 107 & 727 \\
\hline \multicolumn{8}{|l|}{ Cyphoderidae } \\
\hline Cyphoderus albinus Nicolet, 1842 & 0 & 7 & 0 & 0 & 0 & 0 & 33 \\
\hline Cyphoderus bidenticulatus Parona, 1888 & 0 & 0 & 0 & 0 & 0 & 0 & 13 \\
\hline \multicolumn{8}{|l|}{ Entomobryidae } \\
\hline Entomobrya corticalis (Nicolet, 1842) & 0 & 0 & 0 & 60 & 287 & 0 & 0 \\
\hline Entomobrya dorsalis Uzel, 1891 & 0 & 0 & 13 & 33 & 33 & 0 & 0 \\
\hline Entomobrya lanuginosa (Nicolet, 1844) & 0 & 0 & 0 & 0 & 0 & 0 & 173 \\
\hline Entomobrya multifasciata (Tullberg, 1871) & 433 & 507 & 220 & 287 & 293 & 87 & 227 \\
\hline Entomobrya muscorum (Nicolet, 1842) & 0 & 0 & 0 & 40 & 53 & 0 & 0 \\
\hline Lepidocyrtus cyaneus Tullberg, 1871 & 0 & 0 & 0 & 0 & 0 & 160 & 727 \\
\hline Lepidocyrtus lanuginosus (Gmelin, 1788) & 133 & 413 & 427 & 360 & 260 & 0 & 313 \\
\hline Lepidocyrtus lignorum (Fabricius, 1793) & 0 & 0 & 0 & 253 & 327 & 0 & 0 \\
\hline Lepidocyrtus nigrescens Szeptyczki, 1967 & 0 & 13 & 0 & 0 & 80 & 0 & 13 \\
\hline Lepidocyrtus paradoxus Uzel, 1890 & 0 & 0 & 0 & 0 & 0 & 0 & 253 \\
\hline Pseudosinella alba (Packard, 1873) & 67 & 407 & 133 & 293 & 60 & 7 & 527 \\
\hline Pseudosinella horaki Rusek, 1985 & 0 & 0 & 0 & 0 & 480 & 0 & 0 \\
\hline Pseudosinella octopunctata Börner, 1901 & 0 & 0 & 0 & 0 & 0 & 0 & 280 \\
\hline Pseudosinella petterseni Börner, 1901 & 20 & 20 & 33 & 0 & 0 & 0 & 233 \\
\hline Pseudosinella sexoculata Schött, 1902 & 0 & 0 & 0 & 0 & 73 & 0 & 0 \\
\hline Pseudosinella cf. wahlgreni (Börner, 1907) & 0 & 0 & 0 & 107 & 193 & 0 & 0 \\
\hline Heteromurus major (Moniez, 1889) & 0 & 0 & 0 & 0 & 0 & 0 & 187 \\
\hline Heteromurus nitidus (Templeton, 1835) & 0 & 40 & 0 & 247 & 20 & 0 & 0 \\
\hline Orchesella cincta (Linnaeus, 1758) & 153 & 13 & 147 & 0 & 13 & 67 & 460 \\
\hline Orchesella flavescens (Bourlet, 1839) & 0 & 0 & 7 & 80 & 227 & 0 & 0 \\
\hline Orchesella multifasciata (Stscherbakow, 1898) & 267 & 580 & 447 & 260 & 267 & 0 & 0 \\
\hline Orchesella spectabilis Tullberg, 1871 & 0 & 0 & 0 & 33 & 167 & 0 & 0 \\
\hline \multicolumn{8}{|l|}{ Isotomidae } \\
\hline Cryptopygus bipunctatus (Axelson, 1903) & 0 & 507 & 13 & 687 & 2773 & 0 & 0 \\
\hline Desoria violacea (Tullberg, 1877) & 0 & 0 & 0 & 0 & 13 & 0 & 0 \\
\hline
\end{tabular}




\section{A 3. táblázat (folytatás)}

Table 3. (cont.)

\begin{tabular}{|c|c|c|c|c|c|c|c|}
\hline Collembola & A12 & AK & T5 & TK & RT & SZ & FSZ \\
\hline Folsomia manolachei Baggnall, 1939 & 833 & 1733 & 567 & 2687 & 3680 & 0 & 0 \\
\hline Folsomia quadrioculata (Tullberg, 1871) & 973 & 1473 & 373 & 1320 & 2940 & 0 & 0 \\
\hline Folsomides parvulus Stach, 1922 & 0 & 0 & 0 & 0 & 0 & 60 & 0 \\
\hline Isotoma anglicana Lubbock, 1862 & 0 & 0 & 0 & 0 & 0 & 53 & 187 \\
\hline Isotoma caerulea (Bourlet, 1839) & 0 & 0 & 0 & 0 & 0 & 7 & 127 \\
\hline Isotoma viridis Bourlet, 1839 & 0 & 0 & 0 & 0 & 0 & 0 & 340 \\
\hline Isotomiella minor (Schäffer, 1896) & 133 & 693 & 347 & 1140 & 2560 & 0 & 0 \\
\hline Parisotoma notabilis (Schäffer, 1896) & 1727 & 2713 & 1660 & 2053 & 2300 & 487 & 2160 \\
\hline Proisotoma minuta (Tullberg, 1871) & 0 & 0 & 20 & 53 & 100 & 0 & 13 \\
\hline \multicolumn{8}{|l|}{ Tomoceridae } \\
\hline Pogonognathellus flavescens (Tullberg, 1871) & 0 & 0 & 0 & 40 & 240 & 0 & 0 \\
\hline Pogonognathellus longicornis (Müller, 1776) & 0 & 0 & 0 & 0 & 13 & 0 & 0 \\
\hline Tomocerus vulgaris (Tullberg, 1871) & 0 & 0 & 0 & 13 & 93 & 0 & 0 \\
\hline \multicolumn{8}{|l|}{ Neelidae } \\
\hline Megalothorax minimus Willem, 1900 & 13 & 160 & 167 & 340 & 720 & 0 & 0 \\
\hline \multicolumn{8}{|l|}{ Bourletiellidae } \\
\hline Bourletiella arvalis (Fitch, 1863) & 0 & 0 & 0 & 0 & 0 & 0 & 60 \\
\hline Fasciosminthurus virgulatus (Skorikow, 1899) & 0 & 0 & 0 & 0 & 0 & 0 & 13 \\
\hline \multicolumn{8}{|l|}{ Arrhopalitidae } \\
\hline Arrhopalites cf. principalis Stach, 1945 & 0 & 0 & 0 & 0 & 100 & 0 & 0 \\
\hline \multicolumn{8}{|l|}{ Katiannidae } \\
\hline Sminthurinus aureus (Lubbock, 1862) & 0 & 0 & 0 & 7 & 0 & 0 & 0 \\
\hline Sminthurinus elegans (Fitch, 1863) & 7 & 140 & 53 & 60 & 60 & 13 & 180 \\
\hline Sphaeridia pumilis (Krausbauer, 1898) & 20 & 447 & 93 & 1447 & 1860 & 0 & 0 \\
\hline \multicolumn{8}{|l|}{ Sminthuridae } \\
\hline Allacma fusca (Linnaeus, 1758) & 0 & 0 & 0 & 13 & 13 & 0 & 0 \\
\hline Sminthurus maculatus Tömösváry, 1883 & 0 & 0 & 0 & 0 & 0 & 7 & 20 \\
\hline Spatulosminthurus flaviceps (Tullberg, 1871) & 0 & 0 & 0 & 0 & 40 & 0 & 0 \\
\hline Lipothrix lubbocki (Tullberg, 1872) & 0 & 27 & 0 & 393 & 707 & 0 & 0 \\
\hline
\end{tabular}

\section{Közösségi ökológiai eredmények}

A vizsgált élöhelyek Collembola közösségeinek legfontosabb karakterisztikáit a 4. táblázatban foglaljuk össze.

A legtöbb fajt a reliktum tölgyesben vett mintákban észleltük, a legalacsonyabb fajszám pedig a művelt szántókra jellemző. Bár a szántóval összehasonlítva az erdősítésekben több fajt detektáltunk, a fajszám és a diverzitás értéke az akácos és a kocsánytalan tölgyes esetében is még elmarad a kontroll élöhelyek közösségeinek értékeitől ( $t$-teszt, $p<0,01)$. A felhagyott szántó jellegzetes ugróvillás-közösségek élettere, amelyre 
a magas fajszám és diverzitás mellett a legnagyobb kiegyenlítettség is jellemző. Az abundancia-viszonyok tekintetében hasonló eredményeket kaptunk, miszerint a legnagyobb ugróvillás-sűrűséget a reliktum tölgyes foltban találtuk. Itt már szembetűnőbb a különbség a müvelt területek és a fiatal erdősítések közösségeit tekintve, utóbbiaknál átlagosan közel 2,5-szer nagyobb ugróvillás-sűrűséget tapasztaltunk. A különböző fafajú telepítéseket tekintve az abundancia, ha nem is számottevően, de az akácosban volt magasabb.

4. táblázat: A vizsgált habitatokra jellemző ugróvillás-közösségek fontosabb karakterisztikáinak átlagértékei

A12 - akácos kísérleti terület, AK - akác kontroll, T5 - kocsánytalan tölgyes kísérleti terület,

TK - kocsánytalan tölgy kontroll, RT - reliktum tölgyes, SZ - szántó, FSZ - felhagyott szántó

Table 4: Mean values of collembola community characteristics in the sampled habitats A12 - Black locust experimental stand, AK - Black locust control, T5 - Sessile oak experimental stand, TK - Sessile oak control, RT - Relict forest, SZ - Arable land, FSZ - Uncultivated arable land

\begin{tabular}{|l|c|c|c|c|c|c|c|}
\hline & A12 & AK & T5 & TK & RT & SZ & FSZ \\
\hline Fajszám (S) & 17,7 & 20,7 & 19,7 & 29,3 & 35,7 & 14,0 & 28,7 \\
\hline Abundancia (egyed $\left./ \mathrm{m}^{2}\right)$ & 6433 & 11780 & 6067 & 14040 & 23033 & 2633 & 12033 \\
\hline Shannon index & 2,307 & 2,513 & 2,424 & 2,696 & 2,747 & 2,050 & 2,899 \\
\hline Egyenletesség & 0,804 & 0,831 & 0,820 & 0,798 & 0,769 & 0,777 & 0,864 \\
\hline
\end{tabular}

Az ugróvillás-közösségek hasonlóságát a Bray-Curtis index alapján végzett hierarchikus cluster-analízis dendrogramja szemlélteti (2. ábra). Az analízis a művelt szántó (I) határozott elkülönülését mutatja. A második nagy csoporton (II) belül a nyílt (II/1) és erdei élőhelyek (II/2) különválása figyelhető meg. Utóbbin belül külön alcsoportot alkotnak az erdőtelepítések (II/2a) és a kontroll erdei élőhelyek (II/2b) közösségei.

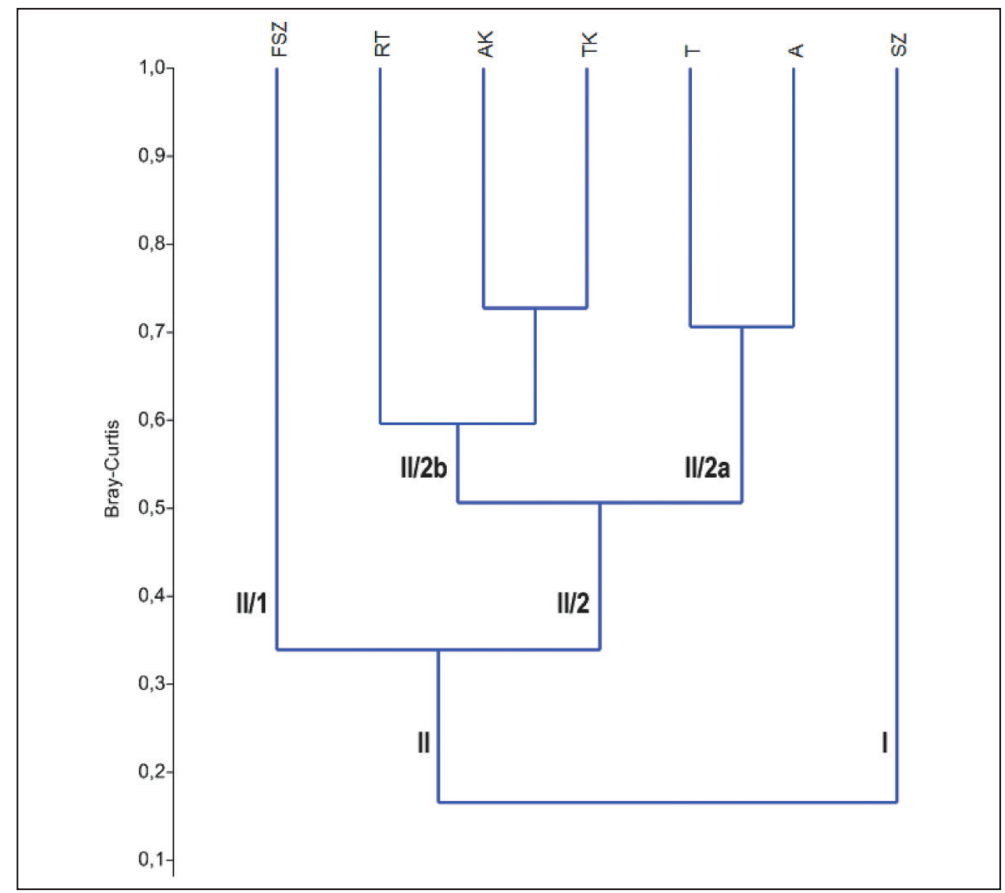

2. ábra: A Bray-Curtis hasonlósági indexen alapuló hierarchikus cluster-analízis dendrogramja Figure 2: Dendrogram based on cluster analysis using the Bray-Curtis index of similarity 


\section{MEGVITATÁS}

Az eredményekböl látható, hogy az akácos kísérleti területen a talajban felhalmozott tápanyagok felhasználása sokkal hatékonyabban valósult meg, mint a tölgyes kísérletben. Ennek egyik oka lehet, hogy a mütrágyázás negatív hatással van az erdőtalaj gomba-biomasszájára (Wallenstein et al 2006), így a tölgyekkel együtt élő mikorrhiza fajokra is (Berki 1999). Ezzel szemben az akáccal szimbiózisban élő rhizóbium baktériumok (Mantovani et al 2015) nitrogénfixáló képessége K-tágyázás hatására hatékonyabb (Berki 1999). Foszfortrágyázás hatására az akác növekedése gyorsabb (Burner 2005, Gruenewald et al 2007), de NPKmütrágyázás hatására az erdők biomasszája és az avar mennyisége is szignifikánsan nő (Tanner et al 1992, Turkington et al 1998). A foszfor hosszú ideig marad ugyan a talajban (Kovács \& Füleky 1991), de a pillangósoknak, így az akácnak is nagy a foszforigénye (Kanzler et al 2015, Loch 1999, Plass 1972), így az akácos talajának foszfortartalma meglehetösen alacsony.

A telepített erdőkben a lombkorona záródása (Oliver \& Larson 1996), illetve az avarvastagság kialakulása (Cunningham et al 2012) a telepítését követő két évtizeden belül lezajilik. A gyorsan növő, idegenhonos fafajok, mint az akác, hatékonyabban képesek a légköri $\mathrm{CO}_{2}$-t megkötni, mint az öshonos kocsánytalan tölgy (Lindenmayer et al 2003), lombkorona-záródásuk gyorsabb, szerkezetük hamarabb kialakul (Haggar et al 1997), amit az optimális kocsánytalan tölgy termöhely biztosit (Bartha et al 2014). Az akácos kísérletben cserjék is előfordulnak, ezáltal az erdőszerkezet fejlettebb (Kanowski et al 2003) és rövidebb idő alatt kialakult (Munro et al 2009). Sőt, az akáclevelek mineralizációja gyorsabb, az optimálisabb C/N arány miatt (Tanteno et al 2007).

A talajfauna vonatkozásában elmondható, hogy - paradox módon - mind az erdöirtás, bizonyos esetekben pedig az erdösités is negatív hatással lehet az ugróvillás-közösségek abundanciájára, diverzitására (Jordana et al 1987, Deharveng 1996, Ponge et al 2006). Bár korábbi adatok nem állnak rendelkezésre a kísérleti terület talajfaunájára vonatkozóan, az intenzív használat és kezelések azonban feltételezhetően degradáló hatással voltak az ugróvillás-közösségekre (pl. Kováč et al 2001, Winkler \& Traser 2017). Ezt igazolja jelen kutatásunkban a kontrollként választott művelt szántó közösségének alacsony fajszáma, diverzitása és abundanciája. Ezzel szemben a felhagyott szántón fajgazdag és abundáns közösséget találtunk, ami összefüggésben lehet a fiatal parlagok növényzetének magas fitomasszaprodukciójával és ennek következtében a nagyobb avarmennyiséggel (Bálint et al 2014).

Az intenzív szántóterületek újraerdősítésének pozitív hatása megmutatkozik a talajfauna eredményekben is. Az abundancia, fajszám és diverzitásértékek, bár elmaradnak a kontroll akác és kocsánytalan tölgyes állományokétól, a környező szántóterületek faunájával összehasonlítva azonban az ültetvényekben szignifikánsan magasabb Collembola diverzitás figyelhető meg. A vizsgált ültetvények talajának kolonizációja azonban lassú folyamat, amit a környező élöhelyekkel (szántó, felhagyott szántó, kevésvé záródott erdősáv) is magyarázhatunk. Míg a felszínen mozgó ugróvillások (pl. Entomobryidae) könnyebben terjedhetnek a kissé távolabbi erdőkböl is, ugyanez nem mondható el a legtöbb euedafikus fajról (pl. Tullbergiidae), amelyek morfológiájában erős redukció (pl. csökevényes ugróvilla vagy annak teljes hiánya) figylehető meg (Salmon \& Ponge 1998). Ezzel is magyarázható, hogy a két ültetvény ugróvillás faunája még átmeneti jellegü, a közösségekben éppúgy megtalálhatók a nyilt habitatok fajai, mint egyes silvicol fajok.

Az újraerdősitéseknél a fafajmegválasztás döntő fontosságú és hosszútávon jelentős hatással lehet a talajra és a talaj biótára. Az idegenhonos faállományok biodiverzitása - így talajfaunája is - eredendően szegényebb, mint az őshonos fafajok alkotta állományoké (Lindenmayer et al 2003). Hazai viszonylatban ezt a megállapítást főként az akác, feketefenyő, erdei fenyő és nemesnyár monokultúrák esetében igazolták (Traser \& Csóka 2001, Traser 2003, Winkler \& Tóth 2012), de ugyanez elmondható bármely egzóta ültetvényre Európa szerte (Klimitzek 1992). Az inváziós fafajok közül nagy jelentőséggel bír az akác, mivel a hazai erdők állományának közel 25\%-át alkotja (Bartha et al 2008) és a szántók újraerdősitése miatt (racionális földhasználat) 
területének növekedése várható (Bartha et al 2014), leginkább kocsánytalan tölgyes klímában (Balogh et al 2006). Az akác komplex hatással van a talaj jellemzőire, leginkább a nitrogén- és nitráttartalom, valamint a szervesanyag-tartalom növelésével (Rice et al 2004, Tateno et al 2007). Az utóbbi jellegzetesség jól tükröződik a vizsgált akác ültetvény kissé magasabb Collembola abundanciájában, összevetve a kocsánytalan tölgyes állománnyal. Mindazonáltal a fajgazdagság, diverzitás és egyenletesség a tölgy ültetvényben volt a magasabb. Ez a jelenség az akác allelopátiás hatásával is magyarázható. Ez a fafaj másodlagos metabolitokat (pl. toxalbuminokat, robint és phasint) képes előallítani és felszabadítani, amelyek gátló hatással lehetnek a fehérjeszintézisre, amit egyes fajok kevésbé tolerálnak (Hui et al 2004, Rahmonov 2009, Lazzaro et al 2018).

\section{ÖSSZEFOGLALÁS}

Az egykori szántóföldi műtrágyázási tartamkísérlet területén létesített akác és kocsánytalan tölgy ültetvény talajfaunája jól jelzi a talajparaméterekben is megmutatkozó változásokat. Az ugróvillás-közösségek fajszáma, diverzitása és abundanciája ugyan elmarad a kontroll erdőállományokétól, a szántóterületek faunájával összehasonlítva azonban magasabb fajgazdagság, diverzitás és ugróvillás-sürüség figyelhető meg. A fafajmegválasztás hatása már jól megmutatkozik a vizsgált fiatal telepítésekben is. Az akác ültetvényben ugyan nagyobb ugróvillás-sűrüséget tapasztaltunk, a fajgazdagság, diverzitás és egyenletesség viszont a kocsánytalan tölgy esetében volt magasabb.

\section{KÖSZÖNETNYILVÁNÍTÁS}

A kutatás az Emberi Erőforrások Minisztériuma ÚNKP-17-3 kódszámú Új Nemzeti Kiválóság Programjának támogatásával készült.

\section{FELHASZNÁLT IRODALOM}

Arneth A., Harrison S.P., Zaehle S., Tsigaridis K., Menon S., Bartlein P.J., Feichter J., Korhola A., Kulmala M., O'Donnell D., Schurgers G., Sorvari S. \& Vesala T. 2010: Terrestrial biogeochemical feedbacks in the climate system. Nature Geoscience 3: 525-532. DOI: 10.1038/ngeo905

Babenko A.B., Chernova N.M., Potapov M.B. \& Stebaeva M.B. 1994: Collembola of Russia and adjacent countries: Family Hypogastruridae. Nauka, Moskow.

Bacsó A., Dezső I., Maul F., Stefanovics P. \& Tusz Zs. 1972: Talajtani gyakorlatok. Egyetemi jegyzet, Agrártudományi Egyetem Mezőgazdaságtudományi Kar, Gödöllö.

Balogh L., Csoboth I., Kovács G. \& Tímár G. 2006: Az akác termesztésének termőhelyi lehetőségei és korlátai. Erdészeti Lapok 141(7-8): 230-233.

Bartha D., Csiszár Á. \& Zsigmond V. 2008: Black locust (Robinia pseudoacacia L.). In: Botta-Dukát Z. \& Balogh L. (eds): The Most Important Invasive Plants in Hungary. Hungarian Academy of Sciences, Institute of Ecology and Botany, Vácrátót. 63-76.

Bartha D., Szmorad F. \& Tímár G. 2014: A fehér akác (Robinia pseudoacacia L.) hazai helyzetének elemzése. http://www. okologia.mta.hu/sites/default/files/BARTHA_es_mtsai_Akac_attekintes_2014_vegleges.pdf

Bálint P., Balogh N., Kelbert B., Radócz Sz. \& Tóth K. 2014: Fitomassza dinamika homoki gyepek szekunder szukcessziója során. Gyepgazdálkodási Közlemények 2014(1-2): 3-10.

Berki I. 1999: Az erdők tápanyag-ellátása. In: Füleky Gy. (ed): Tápanyag-gazdálkodás. Mezőgazda Kiadó, Budapest, $536-558$.

Bray J.R. \& Curtis J.T. 1957: An ordination of the upland forest communities of southern Southern Wisconsin. Ecological Monographs 27: 325-349. DOI: 10.2307/1942268 
Bretfeld G. 1999: Symphypleona. In: Dunger W. (ed): Synopses on Palaearctic Collembola. Vol. 2. Abhandlungen und Berichte des Naturkundemuseums Görlitz 71(1): 1-318.

Burner D.M., Pote D.H. \& Ares A. 2005: Management effects on biomass and foliar nutritive value of Robinia pseudoacacia and Gleditsia triacanthos f. inermis in Arkansas, USA. Agroforestry Systems 65(3): 207-214. DOI: 10.1007/s10457005-0923-9

Buzás I. (ed) 1988: Talaj- és agrokémiai vizsgálati módszerkönyv 2. Budapest, Mezőgazdasági Kiadó.

Buzás I. (ed) 1993: Talaj- és agrokémiai vizsgálati módszerkönyv 1. Budapest, INDA 4231 Kiadó.

CEU 2014: New EU Forest strategy: conclusions adopted by the Council. Council of the European Union, Brussels.

Coleman D. 2008: From peds to paradoxes: Linkages between soil biota and their influences on ecological processes. Soil Biology and Biochemistry 40: 271-289. DOl: 10.1016/j.soilbio.2007.08.005

Cunningham S.C., Metzeling K.J., MacNally R., Thomson J.R. \& Cavagnaro T. R. 2012: Changes in soil carbon of pastures after afforestation with mixed species: sampling, heterogeneity and surrogates. Agriculture, Ecosystems \& Environment 158: 58-65. DOI: 10.1016/j.agee.2012.05.019

Cunningham S.C., MacNally R., Baker P.J., Cavagnaro T.R., Beringer J., Thomson J.R. \& Thompson R.M. 2015: Balancing the environmental benefits of reforestation in agricultural regions. Perspectives in Plant Ecology, Evolution and Systematics 17(4): 301-317. DOI: 10.1016/j.ppees.2015.06.001

Dale V.H., Joyce L.A., McNulty S., Neilson R.P., Ayres M.P., Flannigan M.D., Hanson P.J., Irland L.C., Lugo A.E., Peterson C.J., Simberloff D., Swanson F.J., Stocks B.J. \& Wotton B.M. 2001: Climate change and forest disturbances: climate change can affect forests by altering the frequency, intensity, duration, and timing of fire, drought, introduced species, insect and pathogen outbreaks, hurricanes, windstorms, ice storms, or landslides. BioScience 51(9): 723-734. DOl: 10.1641/0006-3568(2001)051[0723:CCAFD]2.0.CO;2

Dányi L. \& Traser G. 2008: An annotated checklist of the springtail fauna of Hungary (Hexapoda: Collembola). Opuscula Zoologica 38: 3-82.

Deharveng L. 1982: Cle de determination des genres de Neanurinae (Collembola) d'Europe et la region Mediterraneenne, avec description de deux nouveaux genres. Trav. Lab. Ecobiol. Arthr. Edaph. 3: 7-13.

Deharveng L. 1996: Soil Collembola diversity, endemism, and reforestation: a case study in the Pyrenees (France). Conservation Biology 10: 74-84. DOI: 10.1046/j.1523-1739.1996.10010074.x

Dövényi Z. (ed) 2010: Magyarország kistájainak katasztere. MTA FKI, Budapest.

Egnér H.A.N.S., Riehm H. \& Domingo W.R. 1960: Untersuchungen über die chemische Bodenanalyse als Grundlage für die Beurteilung des Nährstoffzustandes der Böden. II. Chemische Extraktionsmethoden zur Phosphor-und Kaliumbestimmung. Kungliga Lantbrukshögskolans Annaler 26: 199-215.

Fjellberg A. 1980: Identification keys to Norwegian Collembola. Norsk Entomol. Forening 1-152.

Fjellberg A. 1998: The Collembola of Fennoscandia and Denmark. Part I.: Poduromorpha. Fauna Entomologica Scandinavica 35: 1-184.

Gilbert-Norton L., Wilson R., Stevens J.R. \& Beard K.H. 2010: A meta-analytic review of corridor effectiveness. Conservation Biology 24(3) 660-668. DOI: 10.1111/j.1523-1739.2010.01450.x

Giller K.E., Beare M.H., Lavelle P., Izac A.-M.N. \& Swift M.J. 1997: Agricultural intensification, soil biodiversity and agroecosystem function. Applied Soil Ecology 6: 3-16. DOI: 10.1016/S0929-1393(96)00149-7

Gruenewald H., Brandt K.V.B., Schneider B.U., Bens O., Kendzia G. \& Hüttl L.F. 2007: Agroforestry systems for the production of woody biomass for energy transformation purposes. Ecological Engineering 29(4): 319-328. DOl: 10.1016/j.ecoleng.2006.09.012

Haggar J., Wightman K. \& Fisher R. 1997: The potential of plantations to foster woody regeneration within a deforested landscape in lowland Costa Rica. Forest Ecology and Management 99(1-2): 55-64. DOI: 10.1016/s03781127(97)00194-1

Hammer Ř., Harper D.A.T. \& Ryan P.D. 2001: PAST: Paleontological Statistics Software Package for Education and Data Analysis. Palaeontologia Electronica 4: 1-9.

Harta I., Gulyás M. \& Füleky Gy. 2016: Mütrágyázás tartamhatásának vizsgálata akácosban. Agrokémia és Talajtan 65(1): 35-45. DOI: 10.1556/0088.2016.65.1.3

Haynes R.J. \& Naidu R. 1998: Influence of lime, fertilizer and manure applications on soil organic matter content and soil physical conditions: a review. Nutrient Cycling in Agroecosystems 51(2): 123-137. DOI: 10.1023/A:1009738307837 
Hooper D.U., Chapin F.S., Ewel J.J., Hector A., Inchausti P., Lavorel S., Lawton J.H., Lodge D.M., Loreau M., Naeem S., Schmid B., Setälä H., Symstad A.J., Vandermeer J. \& Wardle D.A. 2005: Effects of biodiversity on ecosystem functioning: a consensus of current knowledge. Ecological Monographs 75(1): 3-35. DOI: 10.1890/04-0922

Hopkin S.P. 1997: Biology of the Springtails (Insecta: Collembola). Oxford University Press. 1-330.

Hui A., Marraffa J.M. \& Stork C.M. 2004: A rare ingestion of the Black Locust tree. Journal of Toxicology. Clinical Toxicology 42(1): 93-95. DOI: 10.1081/CLT-120028752

Hutcheson K. 1970: A test for comparing diversities based on the Shannon formula. Journal of Theoretical Biology 29(1): 151-154. DOI: 10.1016/0022-5193(70)90124-4

IBM Corp. 2011. IBM SPSS Statistics for Windows, Version 20.0. IBM Corp., Armonk, NY.

Jackson R.B., Jobbágy E.G., Avissar R., Roy S.B., Barrett D.J., Cook C.W., Farley K.A., le Maitre D.C., McCarl B.A. \& Murray B.C. 2005: Trading water for carbon with biological carbon sequestration. Science 310(5756): 1944-1947. DOI: 10.1126/science. 1119282

Jordana R. 2012: Capbryinae \& Entomobryini. In: Dunger W. \& Burkhardt U. (eds): Synopses on Palaearctic Collembola. Vol. 7/1. Soil Organisms 84: 1-390.

Jordana R., Arbea J.I. \& Carlos Simón M.J.L. 1997: Collembola, Poduromorpha. Fauna Iberica, Vol. 8. Museo National de Ciencias Naturales, Madrid. 1-807.

Jordana R., Arbea J.I., Moraza L., Montenegro E., Mateo M.D., Hernandez M.A. \& Herrera L. 1987: Effect of reafforestation by conifers in natural biotopes of middle and South Navarra (Northern Spain). Revue Suisse de Zoologie 94: 491-502. DOl: 10.5962/bhl.part.79528

Kádár I., Márton L., Németh T. \& Szemes I. 2007: Meszezés és mütrágyázás hatása a talajra és növényre a 44 éves nyírlugosi tartamkísérletben. Agrokémia és Talajtan 56(2): 255-270. DOI: 10.1556/Agrokem.56.2007.2.5

Kanowski J., Catterall C.P., Wardell-Johnson G.W., Proctor H. \& Reis T. 2003: Development of forest structure on cleared rainforest land in eastern Australia under different styles of reforestation. Forest Ecology and Management 183(1-3): 265-280. DOI: 10.1016/S0378-1127(03)00109-9

Kanzler M., Böhm C. \& Freese D. 2015: Impact of P fertilisation on the growth performance of black locust (Robinia pseudoacacia L.) in a lignite post-mining area in Germany. Annals of Forest Research 58(1): 39-54. DOI: $10.15287 /$ afr.2015.303

Kováč L., L'uptáčik P., Miklisová D. \& Mati R. 2001: Soil Oribatida and Collembola communities across a land depression in an arable field. European Journal of Soil Biology 37: 285-289. DOI: 10.1016/S1164-5563(01)01106-2

Kovács K. \& Füleky Gy. 1991: Trágyázási tartamkísérlet eredményei Gödöllő barna erdőtalajon. 1972-1990. Gödöllői Agrártudományi Egyetem, Mezőgazdaságtudományi Kar, Talajtani és Agrokémiai Tanszék.

Lavelle P., Bignell D., Lepage M., Wolters V., Pierre-Armand, R., Ineson P., Heal O.W. \& Dhillion S. 1997: Soil function in a changing world: the role of invertebrate ecosystem engineers. European Journal of Soil Biology 33(4): 159-193.

Lazzaro L., Mazza G., d'Errico G., Fabiani A., Giuliani C. Inghilesi A.F., Lagomarsino A., Landi S., Lastrucci L., Pastorelli R., Roversi P.F., Torrini G., Tricarico E. \& Foggi B. 2018: How ecosystems change following invasion by Robinia pseudoacacia: Insights from soil chemical properties and soil microbial, nematode, microarthropod and plant communities. Science of the Total Environment 622-623: 1509-1518. DOI: 10.1016/j.scitotenv.2017.10.017

Lindenmayer D.B., Hobbs R.J. \& Salt D. 2003: Plantation forests and biodiversity conservation. Australian Forestry 66(1): 62-66. DOI: 10.1080/00049158.2003.10674891

Loch J. 1999: A trágyázás agrokémiai alapjai. In: Füleky Gy. (ed): Tápanyag-gazdálkodás. Mezőgazda Kiadó, Budapest, 228-268.

Mäkipää R. 1994: Effects of nitrogen fertilization on the humus layer and ground vegetation under closed canopy in boreal coniferous stands. Silva Fennica 28(2): 81-94. DOI: 10.14214/sf.a9164

Mantovani D., Veste M., Boldt-Burisch K., Fritsch S., Koning L.A. \& Freese D. 2015: Carbon allocation, nodulation, and biological nitrogen fixation of black locust (Robinia pseudoacacia L.) under soil water limitation. Annals of Forest Research 58(2): 1-16. DOI: 10.15287/afr.2015.420

Meyfroidt P. \& Lambin E.F. 2011: Global forest transition: prospects for an end to deforestation. Annual Review of Environment and Resources 36: 343-371. DOI: 10.1146/annurev-environ-090710-143732

Mirmanto E., Proctor J., Green J., Nagy L. \& Suriantata 1999: Effects of nitrogen and phosphorus fertilization in a lowland evergreen rainforest. Philosophical Transactions of the Royal Society of London B: Biological Sciences 354: 18251829. DOI: $10.1098 /$ rstb. 1999.0524 
Munro N.T., Fischer J., Wood J. \& Lindenmayer D.B. 2009: Revegetation in agricultural areas: the development of structural complexity and floristic diversity. Ecological Applications 19(5): 1197-1210. DOI: 10.1890/08-0939.1

Németh T. \& Várallyay Gy. 1998: A trágyázás és tápanyag utánpótlás jelenlegi helyzete és lehetőségei. Agrofórum 9(13): $2-4$.

Ockert J. 2006: Biomasse- und Nährstoffbilanzierung für einen unterschiedlich gedüngten 11jährigen Robinienbestand (Robinia pseudoacacia L.) auf einer ehemaligen landwirtschaftlichen Dauerversuchsfläche bei Gödöllö (Ungarn). Diplomaarbeit, Westungarische Universität, Sopron

Oliver C.D. \& Larson B.C. 1996: Forest stand dynamics. Updated edition. John Wiley and Sons.

Pan Y., Birdsey R.A., Fang J., Houghton R., Kauppi P.E., Kurz W.A., Phillips O.L., Shvidenko A., Lewis S.L., Canadell J.G., Ciais P., Jackson R.B., Pacala S., McGuire A.D., Piao S., Rautiainen A., Sitch S., Hayes D. 2011: A large and persistent carbon sink in the world's forests. Science 333(6045): 988-993. DOI: 10.1126/science.1201609

Paul D., Nongmaithem A. \& Jha L.K. 2011: Collembolan Density and Diversity in a Forest and an Agroecosystem. Open Journal of Soil Science 1(2): 54-60. DOI: 10.4236/ojss.2011.12008

Pielou E.C. 1966: The measurement of diversity in different types of biological collections. Journal of Theoretical Biology 13: 131-144. DOI: 10.1016/0022-5193(66)90013-0

Plass W.T. 1972: Fertilization treatments increase black locust growth on extremely acid surface-mine spoils. Tree Planters' Notes 23(4): 10-12.

Pomorski R.J. 1998: Onychiurinae of Poland (Collembola: Onychiuridae). Genus (Supplement), Polish Taxonomical Society, Wrocław, 1-201.

Ponge J-F., Dubs F., Gillet S., Sousa J.P. \& Lavelle P. 2006: Decreased biodiversity in soil springtail communities: the importance of dispersal and landuse history in heterogeneous landscapes. Soil Biology \& Biochemistry 38: 1158-1161. DOI: 10.1016/j.soilbio.2005.09.004

Potapov M. 2001: Synopses on Palaearctic Collembola: Isotomidae. Abhandlungen und Berichte des Naturkundemuseums Görlitz 73(2): 1-603.

Rahmonov O. 2009: The chemical composition of plant litter of black locust (Robinia pseudoacacia L.) and its ecological role in sandy ecosystems. Acta Ecologica Sinica 29(4): 237-243. DOI: 10.1016/j.chnaes.2009.08.006

Rice S.K., Westerman B. \& Federici R. 2004: Impacts of the exotic, nitrogen-fixing Black locust (Robinia pseudoacacia) on nitrogen-cycling in a pine-oak ecosystem. Plant Ecology 174(1): 97-107. DOI: 10.1023/B:VEGE.0000046049.219 $00.5 a$

Salmon S. \& Ponge J.F. 1998: Responses to light in a soil-dwelling springtail. European Journal of Soil Biology 34(4): 199-201. DOI: 10.1016/S1164-5563(00)86662-5

Shannon C.E. \& Weaver W. 1949: The Mathematical Theory of Communication. University of Illionis Press, Urbana, 1-117.

Sousa J.P., Bolger T., Da Gama M.M., Lukkari T., Ponge J.F., Simón C., Traser G.,Vanbergen A.J., Brennan A., Dubs F., Ivitis E., Keating A., Stofer S. \& Watt A.D. 2006: Changes in Collembola richness and diversity along a gradient of landuse intensity: a pan European study. Pedobiologia 50(2): 147-156. DOI: 10.1016/j.pedobi.2005.10.005

Stefanovits P. 1972: Talajtan. Mezögazda Kiadó. Budapest.

Szováti K., Füleky Gy. \& Tolner L. 2006: Nitrate accumulation in the soil affected by nitrogen fertilization. Bulletin of the Szent István University Gödölllö 2006. 97-104.

Tanner E.V.J., Kapos V. \& Franco W. 1992: Nitrogen and phosphorus fertilization effects on Venezuelan montane forest trunk growth and litterfall. Ecology 73(1): 78-86. DOI: 10.2307/1938722

Tateno R., Tokuchi N., Yamanaka N., Du S., Otsuki K., Shimamura T., Xue Z.D., Wang S.Q. \& Hou Q.C. 2007: Comparison of litterfall production and leaf litter decomposition between an exotic black locust plantation and an indigenous oak forest near Yan'an on the Loess Plateau, China. Forest Ecology and Management 241(1-3): 84-90. DOI: 10.1016/j. foreco.2006.12.026

Thibaud J.M., Shulz H.J. \& Da Gama M.M. 2004: Synopses on Palaearctic Collembola: Hypogastruridae. Abhandlungen und Berichte des Naturkundemuseums Gölitz 75(2): 1-603.

Tolner L., Vágó I., Sipos M., Tolner, I. \& Füleky Gy. 2010: Energiaerdő hatása a talaj nitrát tartalmának mélységi eloszlására. (The effect of energy plantations on the depth distribution of soil nitrate-ions). XII. Nemzetközi Tudományos Napok (12-th International Scientific Days, XII. Internationale Wissenschaftliche Tagung), Gyöngyös, 2010.03.25-26. Programme 174.

Traser Gy. 2003: Hansági nemesnyár és éger erdők ugróvillás (Insecta: Collembola) faunája. Magyar Biológiai Társaság, Budapest. III. Kárpát-medencei Biológiai Szimpózium kiadványa. 153-157. 
Traser Gy. \& Csóka Gy. 2001: A mezofauna - Insecta: Collembola - ásotthalmi fenyő- és tölgyerdők talajában. Erdészeti Kutatások 90: 231-240.

Turkington R., John E., Krebs C.J., Dale M.R.T., Nams V.O., Boonstra R., Boutin S., Martin K., Sinclair A.R.E. \& Smith J.N.M. 1998: The effects of NPK fertilization for nine years on boreal forest vegetation in northwestern Canada. Journal of Vegetation Science 9(3): 333-346. DOI: 10.2307/3237098

UN 2014: The New York Declaration on Forests. United Nations Climate Summit, New York.

UNEP C.A. 2014: Initiative 20 x 20. Climate Action \& United Nations Environment Program, Lima.

Van Straalen, N. 1997: Community structure of soil arthropods as a bioindicator of soil health. In: Pankhurst, C.E., Doube, B.M. \& Gupta, V.V.S.R. (eds): Biological Indicators of Soil Health. CAB International, Wallingford, UK, 235-264.

Wallenstein M.D., McNulty S., Fernandez I.J., Boggs J. \& Schlesinger W.H. 2006: Nitrogen fertilization decreases forest soil fungal and bacterial biomass in three long-term experiments. Forest Ecology and Management 222(1): 459-468. DOI: 10.1016/j.foreco.2005.11.002

Weiner W.M. 1996: Generic revision of Onychiurinae (Collembola: Onychiuridae) with a cladistic analysis. Annales de la Société Entomologique de France 32(2): 163-200.

Winkler D. \& Tóth V. 2012: Effects of Afforestation with Pines on Collembola Diversity in the Limestone hills of Szárhalom (West Hungary). Acta Silvatica et Lignaria Hungarica 8: 9-20. DOI: 10.2478/v10303-012-0001-8

Winkler D. \& Traser Gy. 2017: Talajlakó mezofauna (Collembola) vizsgálatok a Lajta Project területén. Magyar Apróvad Közlemények 13: 213-224. DOI: 10.17243/mavk.2017.213

Zimdars B. \& Dunger W. 1994: Tullbergiinae. In: Dunger W. (ed): Synopses on Palaearctic Collembola. Vol.: I. Abhandlungen und Berichte des Naturkundemuseums Görlitz, 68(3-4): 1-71.

Érkezett: 2018. április 1.

Közlésre elfogadva: 2018. május 20. 